\title{
Anticancer activity of Giloe, Tinospora cordifolia (Willd.) Miers Ex Hook F \& Thoms
}

\begin{abstract}
Recent advances in modern therapy have provided several paradigms to treat cancer. However, cancer can be cured if it is diagnosed in early stage (primary) and its cure in advance stages is still a challenge. Chemotherapy is one of the important modalities to treat cancer either alone or in combination with other therapeutic regimens. The longterm chemotherapy makes tumors refractive to treatment leading to treatment failure. The plant products may be useful due to presence of numerous chemical molecules in them, which may act on cancer cells through multiple mechanisms, making tumor more amenable to treatment with less or no adverse side effects unlike chemotherapy. The present review is focussed on the preclinical studies on the anticancer activity of giloe, Tinospora cordifolia in vitro and in vivo. Giloe and some of its active phytochemicals have been reported to trigger cytotoxic effect in various cultured human cancer cells and also some animal tumors in vivo. The action of giloe on cancer cells is mediated through multiple mechanisms including induction of reactive oxygen species, DNA damage, apoptosis, inhibition of topoisomerase, $\mathrm{NF}-\kappa \mathrm{B}, \mathrm{COX}-\mathrm{II}$ and Nrf2. The downmodulation of $\mathrm{Bcl}-2, \mathrm{Ca}^{2}+$ release, cyclin-dependent kinase (CDK) 2, CDK4, cyclin D, cyclin E, CD147 proteins and attenuated mitochondrial membrane potential accompanied by an augmented expression of Bax activation of various caspases may also contribute to its cytotoxic effect on tumor cells.
\end{abstract}

Keywords: Tinospora cordifolia, anticancer, berberine, palmatine, mice
Volume 12 Issue 2 - 2019

\author{
Ganesh Chandra Jagetia \\ Hiran Magri, India
}

Correspondence: Prof. Ganesh Chandra Jagetia, 10, Maharana Pratap Colony, Sector-13, Hiran Magri, Udaipur-313002, India, Email gc.jagetia@gmail.com

Received: November 20, 2018 | Published: April 03, 2019

\section{Introduction}

The word cancer spreads terror among the patients who are inflicted with the disease and also in the family members and their dear ones. It also drains the emotional and financial resources of the family or individual who suffers from the disease cancer. Due to changes in life style, increasing environmental pollution and use of state of art gadgets, especially for communication has also increased the incidence of cancer. The therapeutic aspect of cancer has undergone a phenomenal change and new state of the art technologies are being used to treat cancer. The recent analysis by NCI, USA shows an overall trend in decline in cancer mortality by $1.5 \%$ per annum especially during 2006-2015. The NCI estimates indicates an annual diagnosis of $1,735,350$ new cases in United States alone and approximately 609,640 deaths during the year $2018 .^{1}$ More than 700,000 cases of cancer are recorded in India and approximately 5,56,400 individuals die of the disease and this figure may increase by five times in the year 2025 . $^{2}$ The annual incidence of cancer may be much higher in this year globally, where the incidence of new cancer cases will increase up to 18.1 million out of which approximately 9.6 million will die of the disease. ${ }^{3}$

The chemotherapy has been the main stay for cancer treatment. It has been given alone or in combination with radiotherapy or surgery to control cancer. ${ }^{4-6}$ The earliest drugs used for cancer chemotherapy in modern medicine are chlorambucil and cyclophosphamide immediately after word war-II. This has led to testing and synthesis of several compounds for cancer treatment experimentally and many of them are used clinically. ${ }^{4}$ The vinca alkaloids have been discovered in late 1950 and they were first isolated from the periwinkle plant Catharanthus roseus, and have been used for the treatment of hematological malignancies effectively. ${ }^{7-9}$ The epipodophyllotoxins etoposide and teniposide extracted from Mayapple, Podophyllum peltatum are clinically used to treat numerous cancers and form an important part of modern cancer chemotherapy treatment regimens. ${ }^{10-12}$ The extraction of taxol from Taxus brevifoila provided a powerful tool in the hands of clinicians to treat several malignancies either alone or in combination regimens. ${ }^{13-15}$ The other natural product that has been added in the paraphernalia of chemotherapy, the camptothecin has been derived from Camptotheca acuminata and has been used in combination with other protocols to effectively to treat many cancers. ${ }^{16,17}$ However, solubility issues and high toxicity have forced to modify this molecule leading to the synthesis of topotecan, irinotecan and belatecan, which have been approved for clinical use. ${ }^{18}$ Doxorubicin is another important drug which has been isolated from Streptomyces peucetius in the 1960s and is in frequent clinical use to treat a variety of tumors. ${ }^{19-23}$ Bleomycin is derived from Streptomyces verticillus, and has been used to treat Hodgkin's lymphoma and testicular tumors. ${ }^{24,25}$ Apart from these drugs there are host of other synthetic molecules which are clinically used to treat cancer in modern medicine.

The major drawback associated with all the modern chemotherapeutic synthetic molecules is that their use triggers adverse side effects during the course of therapy. They are non-specific and are taken by the normal healthy cells causing genomic instability in them. One of the major side effects of chemotherapy is loss of hairs in the individuals receiving chemotherapy. ${ }^{26,27}$ The chemotherapy regimens are associated with nausea, vomiting, anorexia, diarrhoea, oral mucositis, numbness and fatigue..$^{28,29}$ The other adverse side effects of chemotherapy at tissue level include bone marrow suppression, gastrointestinal disorders, nephrotoxicity, neuropathies, cardiotoxicity, pulmonary toxicity etc., which limit the effective use of chemotherapy regimens. ${ }^{25,30-33}$ The chemotherapy also induces second malignancies in the long-term survivors. ${ }^{34,35}$ The constant use of chemotherapy during cancer treatment makes tumors refractive to therapy and they develop chemoresistance to therapy. ${ }^{36}$ This indicates that there is a need for a pharmacophores, which do not have all these adverse side effects during cancer treatment. The present review will focus mainly on the preclinical studies undertaken to treat cancer by giloe, Tinospora cordifolia.

\section{Taxonomic position}

Giloe, Tinospora cordifoila, (Willd.) Miers ex Hook. F. \& Thoms. belongs to family Menispermaceae and is native of India and it is 
also found in Sri Lanka, Malaysia and China. It is a large glabrous, deciduous perennial twiner with succulent stems and papery bark. Its leaves are simple, alternate, cordate, entire, glabrous and 7-9 nerved. Its flowers are yellow in lax racemes, and solitary. Fruits are red when ripe. The stem contains warty tubercles and the surface skin is longitudinally fissured. It is commonly called as Giloe, Gulancha, Guduchi and Amrita in Hindi. Giloe is a Hindu mythological term that refers to the heavenly elixir, which saved divine beings from old age and kept them eternally young. The stems and roots are used as medicine. The taxonomic classification of Tinospora cordifolia is as follows: -

$\begin{array}{ll}\text { Kingdom: } & \text { Plantae } \\ \text { Subkingdom: } & \text { Tracheobionta } \\ \text { Division: } & \text { Magnoliophyta } \\ \text { Class: } & \text { Magnoliopsida } \\ \text { Subclass: } & \text { Ranunculidae } \\ \text { Order: } & \text { Ranunculales } \\ \text { Family: } & \text { Menispermaceae } \\ \text { Genus: } & \text { Tinospora } \\ \text { Species: } & \text { Cordifolia }\end{array}$

\section{Medicinal properties}

Giloe is astringent, anodyne, antiemetic, anthelmintic, antiinflammatory, bitter, sweet, thermogenic, antipyretic, antiperoidic, appetiser, antispasmodic, cardiotonic, carminative, digestive, expectorant, stomachic, constipating, depurative, hematinic, aphrodisiac, rejuvenative, galacto-purifier and tonic. It is useful in the treatment of mouth, duodenal and peptic ulcers. ${ }^{37-43}$ Giloe is an Ayurvedic propriety medicine, which is used by Ayurvedic physicians to treat several disorders including common cold, fever, constipation, acidity, chronic gastritis, ulcerative colitis, heartburn, gall bladder inflammation, loss of appetite, hepatitis, abdominal distension, rheumatoid arthritis, gout, and dysuria. ${ }^{44-51}$ The giloe has no reported side effect however as a precautionary measure it shall not be administered to pregnant and breast-feeding women. It may cause constipation in some individuals and lower blood sugar levels therefore diabetic patients consuming giloe shall monitor the blood sugar level regularly to avoid any complications.

\section{Phytochemistry}

The qualitative analysis of giloe has shown the presence of alkaloids, flavonoids, glycosides, diterpenes, tannins, phytosterols, saponins, phenols resins, fixed oils, carbohydrates, proteins and amino acids. ${ }^{52-54}$ Table 1 shows different phytochemicals that have been isolated from giloe including alkaloid Choline, Magnoflorine, Tinosporin, Palmatine, Isocolumbin, Aporphine, Jatrorrhizine, Tetrahydropalmatine, berberine, Tinocordiside, $\mathrm{N}-$ formylasimilobine $2-\mathrm{O}-\beta-\mathrm{D}-\mathrm{glucopyranosy} \mathrm{l}-(1 \rightarrow 2)-\beta-\mathrm{D}-\mathrm{glucopyranoside}$ (tinoscorside $\mathrm{A}, \quad 1)$ and $\mathrm{N}$-acetylasimilobine $2-\mathrm{O}-\beta-\mathrm{D}-$ glucopyranosyl-(1 $\rightarrow 2)-\beta D$-glucopyranoside (tinoscorside $B$, 2 ), a new clerodane diterpene, tinoscorside $\mathrm{C}$ (3), and a new phenylpropanoid, sinapyl $4-\mathrm{O}-\beta-\mathrm{D}-$ apiofuranosyl- $(1 \rightarrow 6)-\mathrm{O}-\beta-\mathrm{D}-$ glucopyranoside (tinoscorside $\mathrm{D}, 6$ ), palmatine, tetrahydropalmatine, have been isolated from giloe..$^{55-57}$ The glycosides Cordifolioside A, Tinocordiside, Syrigin, 18-norclerodane glycoside were also isolated from giloe. ${ }^{58-61}$ The steroids including Ecdysterone, Makisterone A and Giloinsterol. $\beta$-sitosterol, $\gamma$-sitosterol, stigmasterol have been also reported from giloe. ${ }^{62-65}$ The tinosporafuranol, tinosporafurandiol, tinosporaclerodanol, and tinosporaclerodanoid were also reported from giloe stems. ${ }^{66}$ The difluorozene, vanillin lactoside (glycoside), 5,6-dihydro-9,10-dimethoxybezo[g]-1,3-benzodioxolo[5,6-a] quinolizinium, cordifolioside $\mathrm{A}$, nootkaton-11,12-epoxide, metholene, hexadecanoic acid (palmitic acid), methyl10-trans,12cis-octadecadienoate have been recently isolated from giloe. ${ }^{67}$ Phenol, 2,4-bis(1,1-dimethylethyl), E-15-Hepta-decenal, 3,7,11,15-Tetra methyl-2-Hexa-decen-1-ol, Hepta-Decyl-Trifluoro-Acetate, Trifluoro-acetoxy hexadecane, 9-Eicosene (e)-, 3-ethyl-5-(2ethylbutyl)-Octadecane, Cyclohexane,1,1'-(2-tridecyl-1,3Propanediyl)bis-, 1,4-didecyl- Cyclohexane, Di-n-Decylsulfone and Hexamethyl-Cyclotrisiloxane were also isolated. ${ }^{53}$ The giloe also contains diterpene lactone like Furonlactone, Columbin and Tinosporon. ${ }^{68,69}$ A polysaccharide, arabinogalactan has been isolated from giloe. ${ }^{70}$

Table I The different active constituents isolated from Giloe (Tinospora cordifolia)

\begin{tabular}{|c|c|c|}
\hline Phytochemical & Names of phytochemicals & Reference \\
\hline Alkaloids & $\begin{array}{l}\text { Choline, Magnoflorine, Tinosporin, Palmetine, Isocolumbin, Aporphine alkaloids, Jatrorrhizine, Tetrahydropalmatine, } \\
\text { berberine, Tinocordiside, N-formylasimilobine } 2-O-\beta \text {-D-glucopyranosyl- }(1 \rightarrow 2)-\beta \text {-D-glucopyranoside (tinoscorside } \\
\text { A, 1) and N-acetylasimilobine 2-O- } \beta \text {-D-glucopyranosyl- }(1 \rightarrow 2)-\beta D \text {-glucopyranoside (tinoscorside B, } 2) \text {, } \\
\text { tinoscorside C (3), sinapyl 4-O- } \beta \text {-D-apiofuranosyl- }(1 \rightarrow 6)-O-\beta \text {-D-glucopyranoside (tinoscorside D, } 6) \text {, palmatine, } \\
\text { Tetrahydropalmatine, Isocorydine }\end{array}$ & $55-57$ \\
\hline Steroids & Ecdysterone, Makisterone A Giloinsterol. $\beta$-sitosterol, $\gamma$-sitosterol,stigmasterol & $62-65$ \\
\hline Diterpene lactone & Furonlactone, Columbin, Tinosporon & 68,69 \\
\hline Polysaccharide & Arabinogalactan & 70 \\
\hline Miscellaneous & $\begin{array}{l}\text { Tinosporafuranol, Tinosporafurandiol, Tinosporaclerodanol, and Tinosporaclerodanoid. } \\
\text { Difluorozene, 5,6-dihydro-9,10-dimethoxybezo [g]-1, 3-benzodioxolo[5,6-a] quinolizinium, cordifolioside A, } \\
\text { nootkaton-11,12-epoxide, metholene, hexadecanoic acid (palmitic acid), methyl10-trans,12-cis-octadecadienoate. } \\
\text { Phenol, 2,4-bis(1,1-dimethylethyl), E-15-Hepta-decenal, 3,7,11,15-Tetra methyl-2-Hexa-decen-1-ol, Hepta-Decyl- } \\
\text { Trifluoro-Acetate, Trifluoro-acetoxy hexadecane, 9-Eicosene (e)-, } \\
\text { 3-ethyl-5-(2-ethylbutyl)-Octadecane, Cyclohexane,1,1'-(2-tridecyl-1,3-Propanediyl)bis-, 1,4-didecyl- Cyclohexane, } \\
\text { Di-n-Decylsulfone, Hexamethyl-Cyclotrisiloxane }\end{array}$ & $\begin{array}{l}66 \\
67\end{array}$ \\
\hline
\end{tabular}




\section{Anticancer activity}

The first report on the anticancer activity of giloe was published in the year 1998, where HeLa, the human cervical cancer cells were treated with $0,5,10,25,50$ and $100 \mathrm{mg} / \mathrm{ml}$ of methanol, dichloromethane and aqueous extracts of giloe. The cytotoxic effect of different extracts of giloe were assayed by Pratt and Willis test ${ }^{71}$ and they were found to kill HeLa cells in a concentration dependent manner. These results were further confirmed by clonogenic assay, which also showed a similar result. Treatment of HeLa cells with 5 , $10,25,50$ and $100 \mu \mathrm{g} / \mathrm{ml}$ of methanol, aqueous and dichloromethane extracts reduced the surviving fraction by a factor of $1.4,1.5,1.78,1.96$ and 2.2, respectively. The most effective extract was dichloromethane extract which killed HeLa cells more effectively than the other two extracts. The effect of $5 \mu \mathrm{g} / \mathrm{ml}$ dichloromethane extract was almost similar to $50 \mu \mathrm{g} / \mathrm{ml}$ of methanol and aqueous extracts indicating that it was 10 times more effective than the other two extracts and almost equal to that of doxorubicin. ${ }^{72}$

The cytotoxic effect of $0,1,2,4,5,6$ or $8 \mu \mathrm{g} / \mathrm{ml}$ of dichloromethane extract of giloe was studied in HeLa cells by exposing HeLa cells for $0,1,2,4,6,8,12,18$ or $24 \mathrm{~h}$ with $1-8 \mu \mathrm{g} / \mathrm{ml}$ dichloromethane extract of giloe and $4 \mathrm{~h}$ treatment duration produced maximum cytotoxic effect and it did not increase appreciable with increase in drug exposure time as indicated by clonogenic survival. The clonogenic assay after treatment with different doses of dichloromethane extract of giloe showed a dose dependent decline in the cell survival with a minimum survival at $8 \mu \mathrm{g} / \mathrm{ml}$ dichloromethane extract of giloe. The analysis of glutathione and lipid peroxidation showed that dichloromethane extract of giloe reduced glutathione concentration accompanied by an elevation in the lipid peroxidation and activity of lactate dehydrogenase establishing its antineoplastic action. ${ }^{73}$

The BALB/c mice transplanted with Ehrlich ascites cells for the development of solid tumor in the hind limb and treated with $200 \mathrm{mg} /$ $\mathrm{kg}$ of methanol extract of giloe showed $58.8 \%$ reduction in the tumor volume ${ }^{74}$ They also studied the immunomodulatory effect and showed that methanol extract of giloe increased the bone marrow cellularity, increased phagocytic activity of macrophages followed by increased antibody production in mice. It also increased the antineoplastic activity of cyclophosphamide. ${ }^{74}$

The anticancer activity of dichloromethane extract of giloe was studied in mice transplanted with Ehrlich ascites carcinoma by administering $25,30,40,50$ and $100 \mathrm{mg} / \mathrm{kg}$ of dichloromethane extract of giloe. Administration of different doses of dichloromethane extract of giloe led to a dose dependent increase in tumor-free survival and a maximum number of tumor free survivors was recorded for a dose of $50 \mathrm{mg} / \mathrm{kg}$ dichloromethane extract. This dose has resulted in average survival time and median survival time of 56 and 55days, respectively when compared with 19 days of non-drug treated tumorized mice. The dose of $50 \mathrm{mg} / \mathrm{kg}$ dichloromethane extract of giloe increased 90 day long-term survivors up to $100 \%$, which is equivalent to 4years in man. The effect of $50 \mathrm{mg} / \mathrm{kg}$ dichloromethane extract of giloe was also evaluated in various stages of tumor development, where it was intraperitoneally administered on day $1,3,6,9,12$ or 15 after tumor inoculation and these days have been arbitrarily designated as stage I, II, III, IV or V, respectively for reasons of clarity. The dichloromethane extract of giloe was most effective when it was administered in tumorized mice during stage I, II and III by an increase of 33, 25 and $17 \%$, respectively as indicated by the increase in the number of longterm survivors. However, treatment of tumorized mice with $50 \mathrm{mg} / \mathrm{kg}$ dichloromethane extract at stage IV and V did not increase long-term survivors, despite an increase in average and mean survival times The biochemical analysis of glutathione and lipid peroxidation in the tumorized mice receiving $50 \mathrm{mg} / \mathrm{kg}$ dichloromethane extract showed a time dependent decline in the glutathione up to $12 \mathrm{~h}$ post-treatment and marginal elevation thereafter. This depletion in glutathione was accompanied by a drastic rise in lipid peroxidation, which was highest at $6 \mathrm{~h}$ that declined gradually thereafter. ${ }^{75}$

The $50 \%$ ethanol extract of giloe stems have been reported to reduce proliferation of glioblastomas (C6 glioma) cells in a concentration dependent manner accompanied by enhanced expression of senescence marker, mortalin and its translocation from perinuclear to pancytoplasmic spaces. This extract also exhibited antimigratory and anti-invasive potential indicated by wound scratch assay and alleviated expression of NCAM, PSA-NCAM, MMP-2 and MMP-9. Giloe treatment also arrested C6 cells in G0/G1 and G2/M phase of the cell cycle and suppressed the expression of G1/S phase specific cyclin D1 and anti-apoptotic protein Bcl-xL. ${ }^{76}$

Palmatine an alkaloid extracted from giloe has been reported to reduce tumor incidence in the 7,12-dimethylbenz(a)anthracene (DMBA) induced skin carcinogenesis in mice. This was accompanied by the restoration in glutathione contents and activities of superoxide dismutase and catalase and reduction of DMBA-induced DNA damage in the lymphocytes of carcinogen treated mice. ${ }^{77}$ The other study has reported the chemopreventive action of $(5 \mathrm{R}, 10 \mathrm{R})-4 \mathrm{R}, 8 \mathrm{R}-$ dihydroxy-2S, 3R:15, 16-diepoxycleroda-13(16), 17, 12S:18,1Sdilactone isolated from giloe on the diethylnitrosamine induced hepatocellular carcinoma. Treatment of diethylnitrosamine induced hepatocarcinoma in mice with 16-diepoxycleroda-13(16), 17, 12S:18,1S-dilactone reduced induction of hepatocarcinoma and arrested the diethylnitrosamine -induced decline in glutathione and activities of glutathione peroxidase, superoxide dismutase and catalase and brought the activities of alanine aminotransferase, aspartate aminotransferase and lactate dehydrogenase near to normal. ${ }^{78}$

The DNA damage plays a crucial role in cell death hence the ability of aqueous, methanol and dichloromethane extracts of giloe has been studied in HeLa cells. Different extracts of giloe increased the frequency of micronuclei in a concentration dependent manner and dichloromethane extract was most efficient in producing DNA damage in the form of micronuclei. Giloe extract not only produced single micronuclei but also produced two and more than two micronuclei in a cell indicating their ability to produce complex multiply site of DNA damage that will leave no chances of tumor cell survival. ${ }^{72}$

The ability of different concentration of dichloromethane extract of giloe was studied to trigger molecular DNA damage in HeLa cells by comet assay. Exposure of HeLa cells to $0,1,2,4,6$ or $8 \mu \mathrm{g} / \mathrm{ml}$ dichloromethane extract of giloe led to a concentration dependent rise in the molecular DNA damage and the lowest concentration of $1 \mu \mathrm{g} /$ $\mathrm{ml}$ was able to elevate the baseline DNA damage by 10 folds, whereas $8 \mu \mathrm{g} / \mathrm{ml}$ dichloromethane extract of giloe, the highest concentration caused a 68 folds rise in the DNA damage, when compared with the untreated control. The estimation of DNA damage at various posttreatment times revealed a time dependent elevation in the DNA damage up to $10 \mathrm{~h}$ post-treatment and a marginal but non-significant decline thereafter up to $24 \mathrm{~h}$ post-treatment, the last assessment time studied..$^{79}$

The active phytochemical present in the dichloromethane was found to be berberine and its anticancer activity has been studied in vitro and in vivo tumor model. Cytotoxicity of berberine chloride (BCL) an isoquinoline alkaloid isolated from Tinospora cordifolia was studied in HeLa cells, by treating them with $8 \mu \mathrm{g} / \mathrm{ml} \mathrm{BCL}$ for $0,1,2,4,6,8$, 12,18 or $24 \mathrm{~h}$. The four hours treatment duration was found to exert maximum cytotoxic effect leading to a $65 \%$ decline in the survival of HeLa cells. Exposure of HeLa cells with 1, 2, 4, 6 or $8 \mu \mathrm{g} / \mathrm{ml} \mathrm{BCL}$ for $4 \mathrm{~h}$ led to a concentration dependent depletion in the clonogenicity of HeLa cells and treatment with $8 \mu \mathrm{g} / \mathrm{ml} \mathrm{BCL}$ reduced the surviving 
fraction to 0.41. Analysis of glutathione-S-transferase (GST) activity, and lactate dehydrogenase (LDH) release at $0,0.5,1,2,4$, 8 and $12 \mathrm{~h}$ post-BCL treatment exhibited a concentration dependent reduction in GST activity accompanied by an increase in the LDH activity. ${ }^{80}$ Berberine has been found to be cytotoxic in SNU-5 gastric carcinoma cells with an IC50 of $48 \mu \mathrm{mol} / \mathrm{L}$. The cytotoxic effect was due to its abiltiy to arrest the cells in G2/M phase of the cell cycle in a concentration dependent manner and by up upregulating the expression of $\mathrm{p} 53$, Wee 1 and $\mathrm{CDk} 1$ proteins followed by a decline in cyclin B. BCL treatment induced apoptosis by upregulating Bax and downregulation of $\mathrm{Bcl}-2, \mathrm{Ca}^{2+}$ release, decline in the mitochondrial membrane potential accompanied by release of mitochondrial cytochrome $\mathrm{C}$ into the cytoplasm and the activation of caspase- $3 .^{81}$ An almost similar effect has been observed in human glioblastoma T98G cells, where berberin caused a concentration dependent rise in the cytotoxicity with an IC50 of $134 \mu \mathrm{g} / \mathrm{ml}$ by arresting cells in the G1 phase. This action was mediated by increased expression of P27 accompanied by the attenuated expression of cyclin-dependent kinase (CDK) 2, CDK4, cyclin D, and cyclin E proteins. It triggered apoptosis by induction of a higher ratio of the $\mathrm{Bax} / \mathrm{Bcl}-2$ proteins, the disruption of mitochondrial membrane potential, and the activation of procaspase-9, caspase-9, caspase-3, and poly(ADP-ribose) polymerase (PARP) ${ }^{82}$ Treatment of MCF-7 and MDA-MB-231 breast cancer cells with berberine induced cytotoxic effect by inducing apoptosis, increasing reactive oxygen species and phosphorylated JNK triggered mitochondria membrane potential $(\Delta \Psi \mathrm{m})$ depolarization and downregulated expression of anti-apoptotic protein Bcl-2 concomitant with the upregulation of pro-apoptotic protein Bax. Downregulation of anti-apoptotic Bcl-2 family protein in parallel with loss of $\Delta \Psi \mathrm{m}$, leading to increased the release of cytochrome $\mathrm{c}$ and apoptosis-inducing factor (AIF) from mitochondria, that eventually triggered the caspasedependent and caspase-independent apoptosis. ${ }^{83}$ Berberine also induced cytoxic effect in hepatoma carcinoma HepG2 and SMMC7721 cells in a dose and time depenent manner by reducing the rexpression CD147 protein. ${ }^{84}$

Administration of mice transplanted with Ehrlich ascites carcinoma (EAC) with $10 \mathrm{mg} / \mathrm{kg} \mathrm{BCL}$ on $1,3,6,9,12$ or 15 days, (stage I, II, III, IV, V and VI) after EAC inoculation increased 58.3\% maximum tumor free survivors at 30days in mice receiving BCL on second day of tumorization. Treatment of tumorized mice with BCL on day 3 and 6 after tumor inoculation also increased the tumor free survivors at 30days. Despite a rise in survival at 30days, no long-term survivors ( $>60$ days) could be reported at any of the stages evaluated. The estimation of lipid peroxidation and GSH contents in EAC cells exhibited a time dependent decline in the GSH activity followed by a rise in lipid peroxidation up to $9 \mathrm{~h}$ post-treatment. ${ }^{85}$

The ability of BCL to inflict DNA damage at molecular level in HeLa cells was determined by comet assay by treating them with 1 , $2,4,6$ or $8 \mu \mathrm{g} / \mathrm{ml}$ of the drug. The BCL was found to increase the molecular DNA damage in a concentration dependent manner up to $24 \mathrm{~h}$ post BCL treatment and the maximum DNA damage was brought by $8 \mu \mathrm{g} / \mathrm{ml} \mathrm{BCL}$. This study shows that the action of BCL is mediated by triggering DNA damage since clonogenicity of HeLa cells reduced with increasing DNA damage. ${ }^{86}$

The exact mechanism of action of anticancer activity of giloe and its phytochemicals is not well known. Giloe may have employed numerous putative mechanisms to bring out anticancer action. The triggering of reactive oxygen species (ROS) formation by giloe may have elevated the antioxidant status of tumor cells leading to DNA damage by hydrolysis, oxidation and electrophilic attack. Giloe has been reported to increase superoxide radicals, and hydrogen peroxide and TNF $\alpha .{ }^{41}$ Giloe has been reported to induce molecular DNA damage and also damage cellular genome that may have killed neoplastic cells. $^{79,87}$ This may be one of the most important mechanisms of tumor cell kill by giloe as severe DNA damage is hallmark of cell mortality. The reduced GST activity and increased lipid peroxidation and LDH are known to trigger DNA damage and subsequently cause cell death. ${ }^{88,89}$ DNA topoisomerases play important role during DNA replication. Topoisomerase I catalyzes the passage of DNA through single strand breaks, whereas topoisomerase II acts on DNA by passing an intact segment of duplex DNA through a transient doublestranded break, which it generates in a separate double helix ${ }^{90-92}$ and inhibition of topoisomerase II leads to the stabilization of DNA double strand 'cleavable complex' and subsequently induce cytotoxic effect. Giloe contains berberine, which has been found to suppress DNA topoisomerase I and II activity and stabilizes the enzyme mediatedDNA “cleavable complex", which may also trigger molecular DNA damage and tumor cell kill. Berberine also arrest telomere elongation inducing cytotoxicity in tumor cells. ${ }^{33}$ Suppression of NF- $\mathrm{\kappa B}, \mathrm{COX}-$ II and Nrf2 may have also played a crucial role in cancer cell death by giloe. Since berberine and giloe have been reported to repress the expression of NF- $\mathrm{KB}, \mathrm{COX}-\mathrm{II}, \mathrm{Nrf} 2$ and STAT3. ${ }^{94-97}$ Berberine present in giloe has been reported to arrest cells in G2/M phase, upregulate the expression of p53, Wee1 and CDk1, Bax, P27 and activation of procaspase -9 , caspase -9 , caspase -3 , and poly (ADPribose) polymerase (PARP) accompanied by downregulation of $\mathrm{Bcl}-$ 2, $\mathrm{Ca}^{2+}$ release, cyclin-dependent kinase (CDK) 2, CDK4, cyclin B, cyclin $\mathrm{D}$, and cyclin $\mathrm{E}$ proteins leading to triggering of apoptosis. ${ }^{81}$

\section{Conclusions}

Giloe and its phytochemicals like palmatine and berberine have been reported to be cytotoxic in various cultured human cell lines and also in some preclinical transplanted tumor models. The cytotoxic effect of giloe and its constituents may be due to their ability to stimulate free radical formation and DNA damage in the tumor cells. They also reduce antioxidant status of tumor cells by increasing lipid peroxidation and lactate dehydrogenase. At molecular level giloe and its phytochemicals may have inhibited topoisomerases that triggered DNA damage causing cytotoxic effects in tumor cells. Suppression of NF- $\mathrm{KB}, \mathrm{COX}-\mathrm{II}, \mathrm{Nrf} 2$, STAT3, of $\mathrm{Bcl}-2, \mathrm{Ca}^{2+}$ release, cyclindependent kinase (CDK) 2, CDK4, cyclin B, cyclin D, and cyclin $\mathrm{E}$ may have induced cytotoxicity in tumor cells. The activation of p53, Wee1 and CDk1 proteins, Bax, P27, procaspase-9, caspase-9, caspase-3, and poly (ADP-ribose) polymerase (PARP) would have led to increase in apoptotic death of tumor cells.

\section{Acknowledgments}

I wish to acknowledge the constant support, encouragement, and patience of my wife Mrs. Mangla Jagetia during the writing of this manuscript.

\section{Conflicts of interest}

The author does not have any Conflicts of interest statement to declare.

\section{References}

1. Siegel RL, Miller KD, Jemal A. Cancer statistics, 2018. CA Cancer J Clin. 2018;68(1):7-30.

2. IARC. World Cancer Report 2014. In: Stewart, CP Wild, Editors. IARC, Cedex: France; 2017.

3. Bray F, Ferlay J, Soerjomataram I, et al. Global Cancer Statistics 2018: GLOBOCAN Estimates of Incidence and Mortality Worldwide for 36 
Cancers in 185 Countries. CA Cancer J Clin. 2018;68(6):394-424.

4. DeVita VT, Chu E. A history of cancer chemotherapy. Cancer Res. 2008;68(21):8643-8653.

5. Morgan G, Wardy R, Barton M. The contribution of cytotoxic chemotherapy to 5-year survival in adult malignancies. Clin Oncol. 2004:16(8):549-560.

6. Foo M, Crosby T, Rackley T, et al. Role of (chemo)-radiotherapy in resectable gastric cancer. Clin Oncol. 2014;26(9):541-550.

7. Duflos A, Kruczynski A, Barret JM. Novel aspects of natural and modified vinca alkaloids. Curr Med Chem Anti-Cancer Agents 2002:2(1):55-70

8. Zhang Y, Yang SH, Guo XL. New insights into vinca alkaloids resistance mechanism and circumvention in lung cancer. Biomed Pharmacother. 2017;96:659-666.

9. Martino E, Casamassima G, Castiglione S, et al. Vinca alkaloids and analogues as anti-cancer agents:looking back, peering ahead. Bioorg Med Chem Lett. 2018;28(17):2816-2826.

10. Groninger E, Proost JH, De Graaf SS. Pharmacokinetic studies in children with cancer. Crit Rev Oncol Hematol. 2004;52(3):173-197.

11. Yu X, Che Z, Xu H. Recent advances in the chemistry and biology of podophyllotoxins. Chemistry-Eur J. 2017;23(19):4467-4526.

12. Ahlstrom M, Sloth M, Eriksson M. Trofosfamide and etoposide - A well tolerated palliative treatment for adults with advanced soft tissue sarcoma: A single center experience. J Sarcoma Res. 2017;1(1):1006.

13. Sledge GW, Neuberg D, Bernardo P, et al. Phase III trial of doxorubicin, paclitaxel, and the combination of doxorubicin and paclitaxel as frontline chemotherapy for metastatic breast cancer:an intergroup trial (E1193). J Clin Oncol. 2003;21(4):588-592.

14. Zasadil LM, Andersen KA, Yeum D, et al. Cytotoxicity of paclitaxe in breast cancer is due to chromosome missegregation on multipolar spindles. Sci Transl Med. 2014;6(229):229-243.

15. Barbuti AM, Chen ZS. Paclitaxel through the ages of anticancer therapy:exploring its role in chemoresistance and radiation therapy. Cancers. 2015;7(4):2360-2371.

16. Venditto VJ, Simanek EE. Cancer therapies utilizing the camptothecins a review of the in vivo literature. Mol Pharmaceut. 2010;7(2):307-349.

17. Hu M, Huang P, Wang Y, et al. Synergistic combination chemotherapy of camptothecin and floxuridine through self-assembly of amphiphilic drug-drug conjugate. Bioconj Chem. 2015;26(12):2497-2506.

18. Khazir J, Mir BA, Pilcher L, Riley DL. Role of plants in anticancer drug discovery. Phytochem Lett. 2014;7:173-181.

19. Arcamone F, Cassinelli G, Fantini G, Grein A, Orezzi P, Pol C, Spalla C. Adriamycin, 14-hydroxydaunomycin, a new antitumor antibiotic from S. peucetius var. caesius. Biotechnol Bioeng. 1969;9:1101-1110.

20. Minotti G, Menna P, Salvatorelli E, et al. Anthracyclines:molecular advances and pharmacologic developments in antitumor activity and cardiotoxicity. Pharmacol Rev. 2004;56(2):185-229.

21. Quiles JL, Ochoa JJ, Huertas JR, et al. Olive oil and mitochondria oxidative stress: studies on adriamycin toxicity, physical exercise and ageing. In Quiles JL, CABI Publishing, Oxford. 2006;119-151.

22. Volkova M, Russell R. Anthracycline cardiotoxicity:prevalence, pathogenesis and treatment. Curr Cardiol Rev. 2011;7(4):214-220.

23. Tam K. The Roles of Doxorubicin in Hepatocellular Carcinoma ADMET \& DMPK 2013;1(3):29-44
24. Umezawa H, Maeda K, Takeuchi T, et al. New antibiotics, bleomycin A and B. Journal of Antibiotics (Tokyo). 1966;19(5):200-209.

25. Froudarakis M, Hatzimichael E, Kyriazopoulou L, et al. Revisiting bleomycin from pathophysiology to safe clinical use. Crit Rev Oncol Hematol. 2013;87(1):90-100.

26. Trueb RM. Chemotherapy-induced hair loss. Skin Therapy Lett. 2010;15(7):5-7.

27. Muth CC. Chemotherapy and hair loss. JAMA. 2017;317(6):656.

28. Bloechl-Daum B, Deuson RR, Mavros P, et al. Delayed nausea and vomiting continue to reduce patients' quality of life after highly and moderately emetogenic chemotherapy despite antiemetic treatment. $J$ Clin Oncol. 2006;24(27):4472-4478.

29. Ruhlmann $\mathrm{CH}$, Iversen $\mathrm{TZ}$, Okera M, et al. Multinational study exploring patients' perceptions of side-effects induced by chemoradiotherapy. Radiother Oncol. 2015;117(2):333-337.

30. Cavaletti G, Alberti P, Frigeni B, et al. Chemotherapy-induced neuropathy. Curr Treat Opt Neurol. 2011;13(2):180-190.

31. Staff NP, Grisold A, Grisold W, Windebank AJ. Chemotherapy-induced peripheral neuropathy: A current review. Ann Neurol. 2017;81(6):772781.

32. Fung C, Dinh P, Ardeshir-Rouhani-Fard S, et al. Toxicities Associated with Cisplatin-Based Chemotherapy and Radiotherapy in Long-Term Testicular Cancer Survivors. Adv Urol. 2018;2018.

33. Campia U, Barac A. Cardiovascular side effects of cancer treatments Lung Cancer. 2018;15:05.

34. Bazire L, De Rycke Y, Asselain B, et al. Risks of second malignancies after breast cancer treatment:long-term results. Cancer Radiothérapie. 2017;21(1):10-15.

35. Scholz-Kreisel P, Kaatsch P, Spix C, et al. Second Malignancies Following Childhood Cancer Treatment in Germany From 1980 to 2014:A Registry-Based Analysis. Deut Ärzt Int. 2018;115(23):385

36. Gillet JP, Efferth T, Remacle J. Chemotherapy-induced resistance by ATP-binding cassette transporter genes. Biochim Biophys Acta. 2007; 1775(2):237-362.

37. Nadkarni KM, Nadkarni AK. Indian Materia Medica. Mumbai, India: Popular Prakasan Pvt. Ltd; 1976.

38. Li RW, Leach DN, Myers SP, et al. Anti-inflammatory activity, cytotoxicity and active compounds of Tinospora smilacina Benth. Phytomedicine. 2004;18(1):78-83.

39. Rose FM, Noorulla KM, Asma M, et al. In vitro antibacterial activityof methalonic root extract of Tinospora cordifolia (WILLD). Int J Pharma Res Dev. 2007;2(5).

40. Aher VD, Wahi A. Pharmacological study of Tinospora cordifolia as an immunomodulator. Int J Curr Pharmaceut Res. 2010;2:52-54.

41. More P, Pai K. Effect of Tinospora cordifolia (Guduchi) and LPS on release of $\mathrm{H} 2 \mathrm{O} 2 \mathrm{O} 2-$ and $\mathrm{TNF} \alpha$ from murine macrophages in vitro. JPBMS. 2011;4(13).

42. Singh V, Banyal HS. Antimalarial effect of Tinospora cordifolia (Willd.) Hook.f. \& Thoms and Cissampelos pareira L. on Plasmodium berghei. Curr Sci. 2011;101(10):1356-1358.

43. Aranha I, Clement F, Venkatesh YP. Immunostimulatory properties of the major protein from the stem of the Ayurvedic medicinal herb, guduchi (Tinospora cordifolia). J Ethnopharmacol. 2012;139(2):366372. 
44. Pandit RP. Madanpal Nighantu. Mumbai: Khemraj Srikrishnadas Prakashan; 1998. p. 8.

45. Sharma AR. Sushrut Samhita: Sushrutvimarshini Hindi Commentary along with special Deliberation etc. Part II. Varanasi: Chaukhambha Surbharati Prakashan; 2001. pp. 311-317.

46. Kamat SD. Dhanvantari Nighantu. Delhi, India: Chaukhambha Sanskrit Pratisthan; 2002. p. 1

47. Chunekar KC, Pandey GS. Guduchyadi Varga. Bhavprakash Nidhantu. Varanasi: Chaukhambha Bharati Academy; 2006. p. 269.

48. Sharma PV, Sharma GP. Kaiyadeva Nighantu. Varanasi: Chaukhambha Orientalia; 2006. p. 5

49. Tripathi RD. Astanga Samgraha (Sutrasthana) Varanasi: Chaukhambha Sanskrit Pratisthan; 2006. pp. 142-315.

50. Tripathi B. Charak Samhita Part I. Varanasi: Chaukhambha Surbharati Prakashan; 2003. p. 454.

51. Tripathi I. Arkaprakash. Tritiya Shatak. Varanasi: Chaukhambha Krishnadas Academy; 2006. p. 45.

52. Kaur G, Prabhakar PK, Lal UR, et al. Phytochemical and Biological Analysis of Tinospora cordifolia. Int $J$ Toxicol Pharmacol Res. 2016;8(4);297-305.

53. Papitha R, Lokesh R, Kaviyarasi R, et al. Phytochemical screening, FT-IR and gas chromatography mass spectrometry analysis of Tinospora cordifolia (Thunb.) Miers. Int J Pharmacogn Phytochem Res. 2016;8:2020-2024.

54. Kamble N, Puranik DB, Salooja MK. Preliminary phytochemical analysis of aqueous extracts of leaves and stem of Tinospora cordifolia leaves and stem. Int J Eng Technol Sci Res. 2017;4(12):592-596.

55. Kumar S, Verma NS, Pande D, Srivastava PS. In vitro regeneration and screening of berberine in T. cordifolia. J Med Arom Plant Sci. 2000;22:61.

56. Van Kiem P, Van Minh C, Dat NT, et al. Aporphine alkaloids, clerodane diterpenes, and other constituents from Tinospora cordifolia. Fitoterapia. 2010;81(6):485-489.

57. Bajpai V, Singh A, Chandra P, et al. Analysis of phytochemical variations in dioecious Tinospora cordifolia stems using HPLC/QTOF MS/MS and UPLC/QqQLIT-MS/MS. Phytochem Anal. 2016;27(2):92-99.

58. Khan MA, Gray AL, Waterman PG. Tinosporaside, an 18-norclerodane glucoside from T. cordifolia. Phytochemistry. 1989;28:273 -275.

59. Bhatt RK, Sabata BK. Furanoid diterpene glucoside from T. cordifolia Phytochemistry. 1989;28(9):2419-2422.

60. Sipahimalani AT, Noerr H, Wagnor H. Phenyl propenoid glycosides and tetrahydro furanlignan glycosides from the adaptogenic plant drugs $\mathrm{T}$. cordifolia and Drypetes rox burghii. Planta Medica. 1994;60:596-597.

61. Ghosal S, Vishwakarma RA. Tinocordiside A new rearranged cadinane sesquiterpene glycoside from Tinospora cordifolia. J Nat Prod. 1997;60:839-841.

62. Pradhan P, Gangan VD, Sipahimalani AT, et al. Two phytoecdysones from Tinospora cordifolia:Structural assignments by 2D NMR spectroscopy. Ind J Chem Section B. 1997;36:958-962.

63. Maurya R, Handa SS. Tinocordifolin, a sesquiterpene from Tinospora cordifolia. Phytochemistry. 1998;49(5):1343-1346.

64. Gangan VD, Pradhan P, Sipahimalan AT. Phytoecdysones from Tinospora cordifolia:Structural elucidation of ecdysterone and makisterone A by 2D NMR spectroscopy. Ind $J$ Chem Section B. 1997;36:787-792.

65. Chaturvedi P, Sharma VK. Phytosterols from Tinospora cordifolia in vivo and in vitro study. Int J Pharma Bio Sci. 2017;8(3):557-563.
66. Ahmad F, Ali M, Alam P. New phytoconstituents from the stem bark of Tinospora cordifolia Miers. Nat Prod Res. 2010;24(10):926-934.

67. Ramesh J, Kaur A, Mukharjee TK, et al. Phytochemical analysis and Biological studies of Indian medicinal plants Myristica fragrans and Tinospora. Int J Adv Res. 2016;4(5):245-258.

68. Ahmad M, Kazi AB, Karim R, et al. Structure of tinosporide, a furanoid diterpene from Tinospora cordifolia. J Bangladesh Acad Sci. 1978;2:25-30.

69. Hanuman JB, Mishra AK, Sabata B. A natural phenolic lignin from Tinospora cordifolia Miers. J Chem Soc. 1986;1:1181-1186.

70. Chintalwar G, Jain A, Sipahimalani A, et al. An immunologically active arabinogalactan from Tinospora cordifolia. Phytochemistry. 1999;52(6):1089-1093.

71. Pratt RM, Willis WD. In vitro screening assay for teratogens using growth inhibition of human embryonic cells. Proc Natl Acad Sci. 1985;82(17):5791-5794.

72. Jagetia GC, Nayak V, Vidyasagar MS. Evaluation of the antineoplastic activity of guduchi (Tinospora cordifolia) in cultured HeLa cells. Cancer Lett. 1998;127(1-2):71-82.

73. Jagetia GC, Rao SK. Evaluation of cytotoxic effects of dichloromethane extract of guduchi (Tinospora cordifolia Miers ex Hook F \& THOMS) on cultured HeLa cells. Evid Based Complement Alternat Med. 2006;3(2):267-272.

74. Mathew S, Kuttan G. Immunomodulatory and antitumour activities of Tinospora cordifolia. Fitoterapia. 1999;70(1):35-43.

75. Jagetia GC, Rao SK. Evaluation of the antineoplastic activity of guduchi (Tinospora cordifolia) in Ehrlich ascites carcinoma bearing mice. Biol Pharm Bull. 2006;29(3):460-466.

76. Mishra R, Kaur G. Aqueous ethanolic extract of Tinospora cordifolia as a potential candidate for differentiation based therapy of glioblastomas. PLoS One. 2013;8(10):e78764.

77. Ali H, Dixit S. Extraction optimization of Tinospora cordifolia and assessment of the anticancer activity of its alkaloid palmatine. Sci World J. 2013;2013.

78. Dhanasekaran M, Baskar AA, Ignacimuthu S, et al. Chemopreventive potential of Epoxy clerodane diterpene from Tinospora cordifolia against diethylnitrosamine-induced hepatocellular carcinoma. Invest New Drugs. 2009;27(4):347-355.

79. Jagetia GC, Rao SK. The Indian medicinal plant giloe (Tinospora cordifolia) induces cytotoxic effects by damaging cellular DNA in HeLa cells: A comet assay study. Trends Green Chem. 2015;1:1:6.

80. Jagetia GC, Rao SK. Berberine chloride, an isoquinoline alkaloid induces cytotoxicity in cultured HeLa cells. Adv Biotechnol Biochem. 2017;2017:J120.

81. Lin JP, Yang JS, Lee JH, et al. Berberine induces cell cycle arrest and apoptosis in human gastric carcinoma SNU-5 cell line. World $J$ Gastroenterol WJG. 2006;12(1):21.

82. Eom KS, Hong JM, Youn MJ, et al. Berberine induces G1 arrest and apoptosis in human glioblastoma T98G cells through mitochondrial/ caspases pathway. Biol Pharmaceut Bull. 2008;31(4):558-562.

83. Xie $\mathrm{J}, \mathrm{Xu} \mathrm{Y}$, Huang $\mathrm{X}$, et al. Berberine-induced apoptosis in human breast cancer cells is mediated by reactive oxygen species generation and mitochondrial-related apoptotic pathway. Tumor Biol. 2015;36(2):1279-1288

84. Hou Q, Tang X, Liu H, et al. Berberine induces cell death in human hepatoma cells in vitro by downregulating CD147. Cancer Sci. 2011;102(7):1287-1292. 
85. Jagetia GC, Rao SK. Determination of the antineoplastic activity of berberine isolated from Tinospora cordifolia in Swiss albino mice transplanted with Ehrlich ascites carcinoma. J Tumor Med Prev. 2017;1(3):555561.

86. Jagetia GC, Rao SK. Isoquinoline alkaloid berberine exerts its antineoplastic activity by inducing molecular DNA damage in HeLa cells:A comet assay study. Biol Med. 2015;7(1):1.

87. Jagetia GC, Nayak V. Indian medicinal herb guduchi (Tinospora cordifolia Miers) exerts its radiosensitizing activity by accelerating chromosome damage in HeLa cells exposed to different doses of $\gamma-$ Radiation. Med Arom Plant Sci Biotechnol. 2012;6(Special Issue 2):5262.

88. Magtanong L, Ko PJ, Dixon SJ. Emerging roles for lipids in nonapoptotic cell death. Cell Death Differ. 2016;23(7):1099-1109.

89. Gaschler MM, Stockwell BR. Lipid peroxidation in cell death. Biochem Biophys Res Commun. 2017;482(3):419-425.

90. Fujii N, Yamashita Y, Mizukami T, et al. Correlation between the formation of cleavable complex with topoisomerase I and growthinhibitory activity for saintopin-type antibiotics. Mol Pharmacol. 1997;51(2):269-276.

91. Pommier Y, Sun Y, Shar-yin NH, et al. Roles of eukaryotic topoisomerases in transcription, replication and genomic stability. Nat Rev Mol Cell Biol. 2016;17(11):703-721.
92. Hevener KE, Verstak TA, Lutat KE, et al. Recent developments in topoisomerase targeted cancer chemotherapy. Acta Pharmaceut Sinica B. 2018;8(6):844-861.

93. Tillhon M, Ortiz LM, Lombardi P, et al. Berberine:new perspectives for old remedies. Biochem Pharmacol. 2012;84(10):1260-1267.

94. Tiwari M, Dwivedi UN, Kakkar P. Tinospora cordifolia extract modulates COX-2, iNOS, ICAM-1, pro-inflammatory cytokines and redox status in murine model of asthma. J Ethnopharmacol. 2014;153(2):326-337.

95. Pandey MK, Sung B, Kunnumakkara AB, et al. Berberine modifies cysteine 179 of I $\mathrm{B} \alpha$ kinase, suppresses nuclear factor- $\kappa \mathrm{B}-$-regulated antiapoptotic gene products, and potentiates apoptosis. Cancer Res. 2008;68(13):5370-5379.

96. Tsang CM, Cheung YC, Lui VW, et al. Berberine suppresses tumorigenicity and growth of nasopharyngeal carcinoma cells by inhibiting STAT3 activation induced by tumor associated fibroblasts. BMC Cancer. 2013;13(1):619.

97. Li M, Zhang M, Zhang ZL, et al. Induction of apoptosis by berberine in hepatocellular carcinoma HepG2 cells via downregulation of $\mathrm{NF}-\mathrm{\kappa B}$. Oncol Res. 2017;25(2):233-239. 